\title{
THE EFFECTS OF THE MOTTLE AND THE COMMON TOBACCO MOSAIC VIRUSES ON THE YIELD OF VARIETY VIRGINIA 12
}

\author{
J. Adsuar, A. S. Amy, and L. López Matos \\ INTRODUCTION
}

Common tobacco mosaic and other maladies of similar nature are considered to be among the most important, widespread, and destructive diseases affecting tobacco.

A survey recently initiated and still in progress at this Station with the purpose of determining the nature and extent of the mosaics affecting tobacco in Puerto Rico has disclosed that at least two viruses are present in our fields. One of them, the common tobacco mosaic, has been and still is the cause of severe losses to the growers. In spite of that, the attitude of the tobacco farmers in general is one of indifference and many go so far as to maintain that this disease causes no reduction in yield and quality. However, careful observations readily show that the mosaic causes marked retardation in growth and malformation when plants become infected at transplanting, or soon after, and even at later stages of development.

The other virus present is a relative newcomer. It has been named the "mottle" virus and is the cause of a serious disease of sweet peppers grown locally. This virus was presumably first observed here as causing a mosaic on tobacco in $1934(1)^{2}$, but it was not until several years later that its nature was definitely established (2).

Symptomatologically, the mottle virus closely resembles the $\mathrm{Y}$ or veinbanding virus of tobacco and recent studies at this Station to be published in the future strongly suggest that it is, in fact, related to the so-called $Y$ group of viruses.

Mottle is transmitted by mechanical means as well as by the aphid vector Myzus persiceae, Schultz. Until recently this aphid was considered a minor pest of tobacco in Puerto Rico, but during the past two or three years its presence has been alarmingly manifest not only here but in other tobacco-growing regions as well. This interesting phenomenon, now under study by the entomologists, no doubt explains the widespread dissemination of the mottle virus in our fields which, if it continues, will create a serious problem in control.

${ }^{1}$ Phytopathologist, Associate Agronomist in Charge of the Tobaceo Substation, and Research Assistant in Plant Pathology, respectively, Agricultural Experiment Station, University of Puerto Rico, Río Piedras, P. R.

${ }^{2}$ Numbers in parentheses refer to Literature Cited p. 107. 
TABLE 1.-Effects of infection with common tobacoo mosaic and with the mottle virus on the yield of Virginia 12 tobacco

\begin{tabular}{c|c|c}
\hline Symbol & \multicolumn{1}{|c|}{ Virus used } & Mean yield $^{1}$ \\
\hline & & Cwi. per A. \\
A & Mottle & 6.15 \\
B & Tobacco mosaic & 6.16 \\
C & Check & 9.54 \\
\hline
\end{tabular}

${ }^{1}$ Least significant difference between two treatment means: At the 5-percent level $=1.69 \mathrm{cwt}$. per A.; at the 1 -percent level $=3.90 \mathrm{cwt}$. per $\mathrm{A}$.

Common tobacco mosaic and mottle being the two most important virus diseases of tobacco in Puerto Rico up to the present, a field experiment was undertaken to determine, if possible, the effects of each virus individually on the yield and quality of tobacco grown under Puerto Rican conditions.

\section{MATERIALS AND METHODS}

The experiment was located at the Tobacco Substation Farm in Caguas. A $3 \mathrm{ft}$. $x 3 \mathrm{ft}$. Latin-square design was used in laying it out. Each plot consisted of an area equivalent to one one-hundredth of an acre, with 6 rows of 16 plants per plot. Each virus was inoculated separately. The tobacco used was Virginia 12, a local cigar-filler variety. As an added precaution the experimental field was protected by a barbed-wire fence.

The common tobacco-mosaic and the mottle viruses were used for inoculation. Both viruses were kept in pure culture on Virginia 12 tobacco in the laboratory and extracted just before inoculation. Every plant in each plot was inoculated by rubbing two or three leaves of it between the thumb and index fingers previously dipped in the infectious liquid. Care was taken to avoid contamination of one virus with the other.

Before and after inoculation the plants were cultivated, fertilized, and cared for in the usual manner. In addition, they were periodically sprayed with benzene hexachloride (Isotox 250) to prevent aphid infestations.

\section{EXPERIMENTAL DATA}

The data on the effect of infection with the common tobacco mosaic and the mottle virus on tobacco yields are presented in table 1 . As may be seen, the healthy Check (C) outyielded both the mottle-(A) and tobacco-, mosaic-infected (B) plants. There was no significant difference between the adverse effect of the two viruses.

\section{DISCUSSION}

Both common tobacco mosaic and mottle seriously affect tobacco plants in the field. Tobacco-mosaic virus has been present in Puerto Rico for quite 
a long time, but the mottle virus was not definitely reported until very recently. Control of tobacco mosaic is being sought through the use of resistant varieties. Some have already been released elsewhere. The control of mottle through resistant varieties is much more difficult. As far as we know there is no source of resistance to this malady.

From the results presented above it is clear that the common tobacco mosaic as well as the mottle virus reduces the yield of tobacco significantly. According to the data presented there was a loss in yield of approximately 3.38 hundredweights of tobacco per acre directly attributable to infection by either one of the viruses. This represents a monetary loss of about $\$ 114$ per acre.

\section{SUMMARY}

Common tobacco mosaic and mottle are the two most important virus diseases of tobacco in Puerto Rico. A field experiment was carried out at Caguas to determine the effect of these viruses on the yield of tobacco.

Healthy plants of the variety Virginia 12 considerably outyielded plants infected with mottle or with tobacco mosaic. There was no significant difference in the adverse effects of the two viruses, one being as destructive as the other.

The loss in income caused by the viruses was estimated at approximately $\$ 114$ per acre, the loss in yield approximating 3.4 hundredweights per acre.

\section{RESUMEN}

El mosaico común del tabaco y el moteado son las dos enfermedades más importantes del tabaco en Puerto Rico. Ambas enfermedades son causadas por virus. Se eśtableció un experimento en la. Subestación de Tabaco en Caguas, para determinar qué efecto ejercen estos dos virus en el rendimiento del tabaco.

El tabaco sano produjo más que los afectados por cada uno de los virus bajo estudio. No hubo diferencia significativa en cuanto al rendimiento entre las plantas afectadas por uno $\mathrm{u}$ otro virus.

Las pérdidas en ingreso bruto ocasionadas por el efecto de los virus en . el experimento pueden estimarse en alrededor de $\$ 114$ por acre.

\section{LITERATURE CITED}

1. Nolla, J. A. B., First Report of the Tobacco Institute of Puerto Rico, p. 25, 1936-37.

2. Roque, A. and Adsuar, J., Studies on the mosaic of peppers (Capsicum frutescens) in Puerto Rico, J. Agr. Univ. P. R. 25(4) 1-11 1941. 